\title{
PENGARUH KUALITAS LAYANAN PASIEN RAWAT INAP TERHADAP LOYALITAS DI RUMAH SAKIT SEKAR KAMULYAN DENGAN KEPUASAN SEBAGAI VARIABEL MEDIASI \\ NATALIA RETNO BUDI UTAMI ${ }^{*} *$
}

\author{
${ }^{1}$ Magister Manajemen, Fakultas Ekonomi dan Bisnis, Universitas Jenderal Soedirman, Jl. HR. Boenyamin \\ No. 708, Purwokerto 53122, Jawa Tengah, Indonesia \\ Email corresponding author : retnobudi27@gmail.com
}

\begin{abstract}
Abstrak
Penelitian ini bertujuan untuk mengetahui permasalahan kualitas pelayanan berupa tangibles, reliability, responsiveness, assurance, dan empathy yang dirasakan kurang oleh pasien di Rumah Sakit Sekar Kamulyan sehingga dapat dilakukan perbaikan menggunakan Importance and Performance Analysis, serta pengaruhnya terhadap loyalitas, di mana loyalitas dibentuk dari kepuasan pasien melalui analisis regresi berganda (Muh. Abdurrouf, Dyah Wiji Puspita Sari, 2017). Hasil penelitian ini adalah variabel Tangibles, Empathy, dan Assurance berpengaruh secara signifikan terhadap kepuasan, sedangkan variabel Assurance berpengaruh secara signifikan terhadap loyalitas, dan variabel kepuasan berpengaruh secara signifikan terhadap loyalitas. Untuk kualitas layanan tidak ada yang harus diperbaiki, karena tidak ada yang berada di kuadran 1, sehingga secara keseluruan, semua bagus.
\end{abstract}

Kata Kunci: Kualitas Layanan, Kepuasan, Loyalitas

\begin{abstract}
This study aims to determine the service quality problems in the form of tangiable, reliability, responsiveness, assurance, and empathy that are felt less by general patients at Sekar Kamulyan Hospital so that improvements can be made using Importance and Performance Analysis, and their effect on loyalty, where loyalty is formed from patient satisfaction through multiple regression analysis (Muh. Abdurrouf, Dyah Wiji Puspita Sari, 2017). The results of this study are Tangiabel, Empathy, and Assurance variables significantly influence satisfaction, while the Assurance variable has a significant effect on loyalty, and satisfaction variables significantly influence loyalty. For the quality of service there is nothing that must be improved, it is showed that no item quesionnare is in first quadrant, so for overall, quality service in Sekar Kamulyan Hospital is good.
\end{abstract}

Keywords: Service Quality, Satisfaction, Loyalty

\section{PENDAHULUAN}

Berdasarkan undang-undang No. 44 Tahun 2009 tentang rumah sakit, yang dimaksud dengan rumah sakit adalah institusi pelayanan kesehatan yang menyelenggarakan pelayanan kesehatan perorangan secara paripurna yang menyediakan pelayanan rawat inap, rawat jalan, dan gawat darurat. Keadaan ini diperkuat dalam pasal 30 ayat (1) yang menyatakan fasilitas pelayanan kesehatan menurut jenis pelayanannya terdiri dari Pelayanan Kesehatan perorangan dan Pelayanan Kesehatan masyarakat. Rumah sakit harus mempunyai misi memberikan pelayanan kesehatan yang berkualitas, serta terjangkau oleh masyarakat yang membutuhkan dengan tujuan untuk meningkatkan derajat kesehatan masyarakat atau lebih sering disebut pasien.

Pengertian pasien secara umum adalah seseorang yang membutuhkan perawatan di rumah sakit karena kondisi kesehatannya. Pasal 1 Undang-undang No. 29 Tahun 2004 Tentang Praktik Kedokteran menjelaskan definisi pasien adalah setiap orang yang melakukan konsultasi masalah kesehatannya untuk memperoleh pelayanan kesehatan yang diperlukan baik secara langsung maupun tidak langsung oleh dokter atau dokter gigi. Sedangkan dalam UndangUndang no. 44 tahun 2009 tentang rumah sakit dikatakan pasien adalah setiap orang yang melakukan konsultasi masalah kesehatannya untuk memperoleh pelayanan kesehatan yang diperlukan, baik secara langsung maupun tidak langsung di Rumah Sakit. Pelayanan kesehatan 
yang diharapkan pasien adalah pelayanan yang bermutu atau disebut juga sebagai kualitas pelayanan. Kualitas layanan yang baik dapat membuat sebuah rumah sakit menjadi lebih baik.

Servqual atau kualitas pelayanan, diciptakan oleh Parasurman et al., (1985). Servqual dibuat untuk mengevaluasi kinerja layanan yang didasarkan pada lima dimensi yaitu Tangibles (bukti fisik), adalah bukti fisik langsung yang meliputi fasilitas fisik seperti bangunan rumah sakit, perlengkapan dan material yang digunakan rumah sakit serta penampilan karyawan yang bertugas. Realibility (Reliabilitas), berkaitan dengan kemampuan seluruh petugas pemberi layanan di rumah sakit untuk memberikan pelayanan segera dan akurat sejak pasien datang sampai pulang. Responsiveness (Daya tanggap), berhubungan dengan kesediaan dan kemampuan petugas pemberi layanan membantu pasien dan merespon permintaan pasien dengan segera. Assurance (Jaminan), meliputi pengetahuan, keterampilan dan kesopanan yang dapat menumbuhkan rasa percaya pada pasien, jaminan pasien bebas dari bahaya, resiko dan keragu-raguan. Emphaty (Empati) yaitu bahwa setiap pemberi layanan kesehatan dapat berkomunikasi dengan baik, memahami kebutuhan pasien dan bertindak demi kepentingan pasien.

Kepuasan pasien sangat penting bagi sebuah Rumah Sakit dikarenakan dapat membuat sebuah pasien menjadi loyal terhadap sebuah Rumah Sakit. Keadaan ini sesuai dengan penelitian yang dilakukan oleh Rizal, R., Suardi, M., dan Yulihasri (2017) yang mengatakan bahwa kepuasan pasien dipengaruh secara positif oleh kualitas pelayanan pada dimensi daya tanggap (responsiveness), jaminan (assurance), dan bukti langsung (tangibles), dan kepuasan secara keseluruhan mempengaruhi secara positif terhadap loyalitas pasien.

Penelitian ini bertujuan untuk mengetahui masalah Servqual yang terjadi di Rumah Sakit Sekar Kamulyan, serta untuk melihat bagaimana pengaruhnya terhadap kepuasan dan loyalitas pasien yang nantinya akan membuat pasien menjadi lebih loyal.

\section{TINJAUAN PUSTAKA DAN PERUMUSAN HIPOTESIS}

\section{KUALITAS PELAYANAN}

Menurut Pasuraman et.al., (1988), kualitas layanan terdiri dari lima dimensi, yaitu Tangibles (bukti fisik) adalah mutu pelayanan yang terkait dengan ketersediaan informasi mengenai layanan yang ada di rumah sakit, kemudahan untuk mendapatkan layanan tsb, serta penampilan fisik ruang rawat inap yang meliputi kebersihan dan kerapihan kamar pasien, serta fasilitas lain yang ada di ruang rawat inap dan penampilan perawat dan petugas lain yang ada di ruang rawat inap. Ketika Seorang pasien diputuskan oleh dokter untuk dirawat karena kondisi penyakitnya, sebelum menyetujui, pasien akan melihat dan menilai proses awal yang dialami termasuk kemudahan mereka melalui proses administrasi. Kemudahan dan ketersediaan informasi yang dibutuhkan menjadi tolok ukur pertama yang akan memberikan kesan pasien terhadap kualitas pelayanan. Selanjutnya adalah persepsi pasien terhadap penampilan fisik kamar tempat mereka akan dirawat. Pasien rawat inap pada umumnya menginginkan kamar yang baik sesuai dengan keinginan dan apa yang dijanjikan kepada mereka pada tahap awal pemesanan kamar.

Reliability (kehandalan), yaitu kemampuan untuk memberikan pelayanan tepat waktu dan akurat sesuai dengan yang ditetapkan. Responsiveness (daya tanggap), yaitu kesediaan petugas untuk memberikan pelayanan yang cepat sesuai prosedur dan mampu memenuhi harapan pelanggan.

Assurance (jaminan), yaitu berhubungan dengan rasa aman dan kenyamanan pasien karena adanya kepercayaan pasien terhadap petugas yang memiliki kompetensi, kredibilitas dan ketrampilan yang tepat dalam memberikan pelayanan dan pasien memperoleh jaminan pelayanan yang aman dan nyaman. Jaminan/keyakinan meliputi kemampuan karyawan atas pengetahuan terhadap produk/jasa secara tepat, kualitas keramahtamahan, perhatian dan kesopanan dalam memberikan pelayanan, ketrampilan dalam memberikan informasi, kemampuan di dalam memberikan keamanan di dalam memanfaatkan jasa yang ditawarkan, dan kemampuan di dalam menanamkan kepercayaan pasien terhadap pelayanan rumah sakit. 
Emphaty (empati), berhubungan dengan kepedulian dan perhatian petugas kepada setiap pelanggan/pasien dengan mendengarkan keluhan dan memahami kebutuhan serta memberikan kemudahan bagi seluruh pelanggan/pasien dalam menghubungi petugas. Pasien sebagai orang sakit pada umumnya sangat mengharapkan perhatian dari orang-orang yang ada di sekitarnya Empati merupakan perhatian yang diberikan petugas pemberi layanan ke pelanggan/pasien.

\section{KEPUASAN}

Chakraborty, R dan Majundar, A (2011) kepuasan merupakan penilaian individu yang dikumpulkan dari beberapa pengalaman mengenai objek atau peristiwa yang dialami dari waktu ke waktu. Menurut Kotler et al.(2011), Kepuasan juga dapat didefinisikan sebagai keadaan yang dirasakan seseorang baik berupa kesenangan maupun ketidaksenangan yang selanjutnya dibandingkan dengan apa yang diharapankannya.

Menurut Badri., Attia,S.,and Ustadi (2009) terdapat hubungan yang kuat antara kualitas layanan dengan kepuasan pelanggan. Persepsi pelanggan terhadap kualitas produk atau layanan membawa kepuasan dalam pikiran pelanggan. Dalam konteks layanan kesehatan, pasien dianggap sebagai pelanggan layanan kesehatan yang secara sadar membuat pilihan untuk membeli layanan yang paling sesuai dengan kebutuhannya.

\section{LOYALITAS}

Loyalitas menurut Oliver (1997) dalam Ferrinadewi dan Djati (2004) adalah keadaan atau kondisi di mana seorang konsumen, dalam penelitian ini adalah pasien, memiliki keterlibatan yang kuat dalam melakukan pembelian ulang, atau datang kembali ke rumah sakit. Conatively Loyal, keinginan untuk melakukan pembelian ulang yang sangat kuat dan memiliki keterlibatan tinggi yang merupakan sebuah dorongan motivasi untuk datang kembali ke rumah sakit jika mengalami sakit lagi, serta melakukan rekomendasi kepada orang lain, dikarenakan adanya ikatan yang kuat terhadap rumah sakit tersebut.

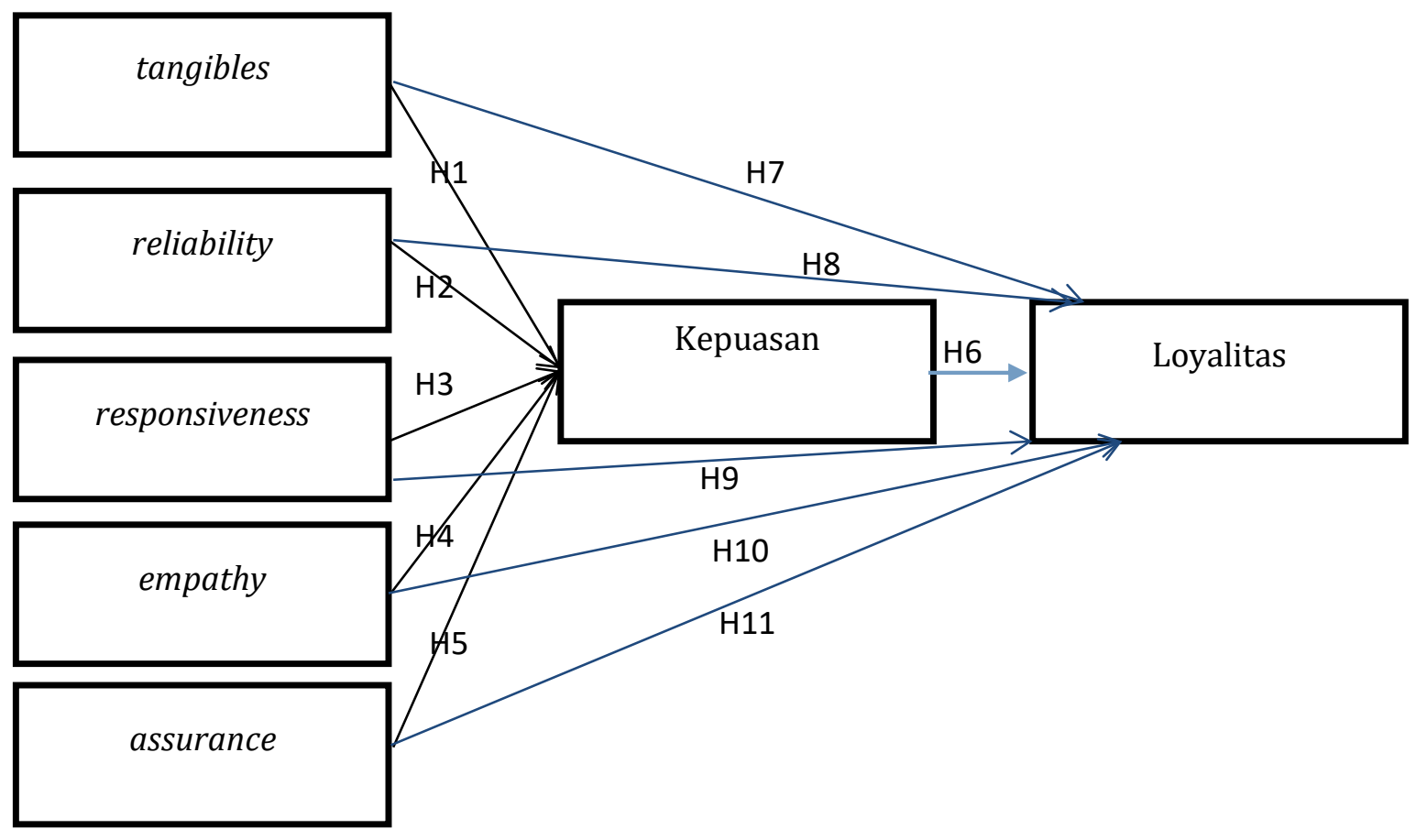

Gambar 1. Kerangka Berpikir

(Sumber: Parasuraman (1988), Siswati, S (2016), Nesa, C.M., et.al. (2017)) 
Peneliti mencoba fokus pada teori awal menurut Parasuraman et.al., (1988) bahwa kepuasan dipengaruhi oleh tangibles, reliability, responsiveness, assurance dan emphaty. Sedangkan penelitian Rizal, R., Suardi, M., dan Yulihasri (2017), mengatakan bahwa kepuasan pasien berpengaruh signifikan terhadap loyalitas pasien.

Berdasarkan literatur yang ada maka peneliti merumuskan hipotesis sebagai berikut:

H1 : Tangibles berpengaruh terhadap kepuasan pasien yang dirawat inap

H2 : Reliability berpengaruh terhadap kepuasan pasien yang dirawat inap

H3 : Emphaty berpengaruh terhadap kepuasan pasien yang dirawat inap

H4 : Responsiveness berpengaruh terhadap kepuasan pasien yang dirawat inap

H5 : Assurance berpengaruh terhadap kepuasan pasien yang dirawat inap

H6 : Kepuasan pasien yang dirawat inap berpengaruh terhadap loyalitas.

H7 : Tangibles berpengaruh terhadap loyalitas melalui kepuasan pasien yang dirawat inap

H8 : Reliability berpengaruh terhadap loyalitas melalui kepuasan pasien yang dirawat inap

H9 : Emphaty berpengaruh terhadap loyalitas melalui kepuasan pasien yang dirawat inap

H10 : Responsiveness berpengaruh terhadap melalui kepuasan loyalitas pasien yang dirawat inap

H11 : Assurance berpengaruh terhadap loyalitas melalui kepuasan pasien yang dirawat inap

\section{METODE PENELITIAN}

Metode deskriptif berguna untuk melakukan gambaran, atau penjelasan mengenai keadaan kualitas pelayanan serta tingkat kepuasan pasien dan loyalitas yang diberikan oleh Rumah Sakit Sekar Kamulyan. Sedangkan untuk metode verifikatif merupakan suatu metode yang berguna untuk menguji teori dari penelitian ini sehingga mendapatkan informasi ilmiah yaitu status hipotesis, yang merupakan asumsi atau dugaan sementara sehingga dapat diterima atau ditolak (Sugiyono, 2017).

Populasi yang digunakan pada penelitian ini adalah semua pasien yang dirawat pada periode bulan Agustus 2018 di unit perawatan dewasa. Pasien rawat inap dewasa berjumlah 809 pasien.

Ukuran sampel ditentukan dengan pendekatan statistika menggunakan rumus Slovin :

$$
n=\frac{N}{1+N e^{2}}
$$

Tingkat kepercayaan yang digunakan sebesar 95\% karena menggunakan $\alpha=0,05$, sehingga diperoleh nilai $Z=1,96$; Keragaman populasi yang digunakan adalah keragaman populasi $\mathrm{P}(1-\mathrm{P})$ dimana $\mathrm{P}$ menggunakan keragaman maksimum yaitu sebesar 0,5 . Berdasarkan rumus tsb, diperoleh sampel sebanyak: minimal 412 responden. Teknik sampling adalah teknik pengambilan sampling yang digunakan untuk menarik, atau memilih sampel. Pada penelitian ini, peneliti menggunakan teknik accidental sampling. Accidental sampling adalah cara pengambilan sampel dengan cara mengambil obyek atau subyek responden yang kebetulan ada atau tersedia di suatu tempat sesuai dengan konteks penelitian (Sugiyono dalam Hayati, 2012).

Jenis data yang digunakan dalam penelitian ini adalah data primer dan data sekunder. Data primer didapat secara langsung oleh peneliti pada saat penelitian di lapangan, yaitu dengan menggunakan kuesioner. Kuesioner dalam penelitian berisi pertanyaan-pertanyaan yang berhubungan dengan penelitian yang sedang dilaksanakan meliputi data yang dikumpulkan meliputi tangibles, responsiveness, reliability, empathy, assurance, kepuasan pasien, serta loyalitas pasien.

Instrumen penelitian yang digunakan disusun berdasarkan item-item kuesioner yang sudah digunakan pada penelitian sebelumnya dalam Pasuraman,A., et.al. (1988), "SERVQUAL : multiple-item scale for measuring consumer perceptions of service quality", dengan adaptasi item- 
item kuesioner. Hal ini dilakukan untuk memperoleh validitas item-item penyusun konstruk penelitian (construct validity), dan Kepuasan serta Loyaltias Pasien yang mengadaptasi dari Kotler \& Armstrong (2011).

Analisa data dilakukan untuk mencari kemaknaan hubungan antara variabel bebas yang meliputi tangibles, responsiveness, reliability, emphaty dan assurance pasien rawat inap dengan variabel terikat kepuasan layanan menggunakan analisa regresi linier berganda, Importance and Performance Analysis, dan pengolahan datanya dengan bantuan software SPSS versi 20.0.

Tahapan analisis data adalah sebagai berikut: Tabulasi data/persiapan data, Uji Validitas, Uji Reliabilitas, Pengujian asumsi klasik, Importance and Performance Analysis, Interpretasi Model Regresi Linier Berganda, Intrepretasi Path Analysis.

\section{HASIL DAN PEMBAHASAN}

Tabel 1. Jenis Kelamin

\begin{tabular}{llrrrr}
\hline & & Frequency & Percent & $\begin{array}{c}\text { Valid } \\
\text { Percent }\end{array}$ & $\begin{array}{c}\text { Cumulative } \\
\text { Percent }\end{array}$ \\
\hline \multirow{3}{*}{ Valid } & Pria & 372 & 54,9 & 54,9 & 54,9 \\
& Wanita & 306 & 45,1 & 45,1 & 100,0 \\
& Total & 678 & 100,0 & 100,0 & \\
\hline
\end{tabular}

Sumber: pengolahan data SPSS

Berdasarkan dari tabel 1 didapatkan bahwa jenis kelamin Pria berjumlah 372 responden, dan Wanita 306 responden.

Tabel 2 Umur

\begin{tabular}{|c|c|c|c|c|c|}
\hline & & Frequency & Percent & $\begin{array}{c}\text { Valid } \\
\text { Percent }\end{array}$ & $\begin{array}{c}\text { Cumulative } \\
\text { Percent }\end{array}$ \\
\hline \multirow{6}{*}{ Valid } & $15-24$ tahun & 54 & 8,0 & 8,0 & 8,0 \\
\hline & 25 - 34 tahun & 268 & 39,5 & 39,5 & 47,5 \\
\hline & $35-49$ tahun & 246 & 36,3 & 36,3 & 83,8 \\
\hline & $50-64$ tahun & 89 & 13,1 & 13,1 & 96,9 \\
\hline & $\begin{array}{l}\text { diatas } 65 \\
\text { tahun }\end{array}$ & 21 & 3,1 & 3,1 & 100,0 \\
\hline & Total & 678 & 100,0 & 100,0 & \\
\hline
\end{tabular}

Berdasarkan tabel 2 didapatkan bahwa responden dengan umur 15 - 24 tahun sebanyak 54 responden, umur 25 - 34 tahun sebanyak 268 responden, 35 - 49 tahun sebanyak 246 responden, 50 - 64 tahun, berjumlah sebanyak 89 responden, dan responden yang berada di atas 65 tahun berjumlah sebesar 21 responden

Tabel 3. Pekerjaan

\begin{tabular}{|c|c|c|c|c|c|}
\hline & & Frequency & Percent & $\begin{array}{c}\text { Valid } \\
\text { Percent }\end{array}$ & $\begin{array}{c}\text { Cumulative } \\
\text { Percent }\end{array}$ \\
\hline \multirow{9}{*}{ Valid } & Pelajar/mahasiswa & 11 & 1,6 & 1,6 & 1,6 \\
\hline & Pegawai Negri & 79 & 11,7 & 11,7 & 13,3 \\
\hline & Pegawai swasta & 197 & 29,1 & 29,1 & 42,3 \\
\hline & Buruh & 103 & 15,2 & 15,2 & 57,5 \\
\hline & Pedagang & 85 & 12,5 & 12,5 & 70,1 \\
\hline & Petani & 34 & 5,0 & 5,0 & 75,1 \\
\hline & Ibu Rumah Tangga & 153 & 22,6 & 22,6 & 97,6 \\
\hline & tidak bekerja & 16 & 2,4 & 2,4 & 100,0 \\
\hline & Total & 678 & 100,0 & 100,0 & \\
\hline
\end{tabular}

Sumber: pengolahan data SPSS 
Berdasarkan tabel 3 responden dengan pekerjaan pelajar atau mahasiswa sebanyak 11 responden, pegawai negeri 79 responden, pegawai swasta sebanyak 197 responden, buruh sebanyak 103 responden, pedagang sebanyak 85 responden, petani sebanyak 34 responden, ibu rumah tangga sebanyak 153 responden, dan yang tidak bekerja sebanyak 16 responden.

Tabel 4. Pendidikan Terakhir

\begin{tabular}{llrrrr}
\hline & Frequency & Percent & $\begin{array}{c}\text { Valid } \\
\text { Percent }\end{array}$ & $\begin{array}{c}\text { Cumulative } \\
\text { Percent }\end{array}$ \\
\hline \multirow{2}{*}{ SD } & 106 & 15,6 & 15,6 & 15,6 \\
& SLTP & 112 & 16,5 & 16,5 & 32,2 \\
SLTA & 274 & 40,4 & 40,4 & 72,6 \\
& DIPLOMA & 83 & 12,2 & 12,2 & 84,8 \\
& S-1 & 95 & 14,0 & 14,0 & 98,8 \\
& S-2 & 6 &, 9 &, 9 & 99,7 \\
& lain-lain & 2 &, 3 &, 3 & 100,0 \\
Total & 678 & 100,0 & 100,0 & \\
\hline
\end{tabular}

Sumber: pengolahan data SPSS

Berdasarkan tabel 4 mengenai latar belakang pendidikan terakhir mendapatkan data bahwa responden yang memiliki latar belakan SD adalah 106 responden, SLTP sebanyak 112 responden, SLTA sebanyak 274 reponden, DIPLOMA sebanyak 83 responden, S- 1 sebanyak 95 responden, dan S-2 sebanyak 6 responden, dan lain-lain sebesar 2 .

Tabel 5. Lama Dirawat

\begin{tabular}{llrrrr}
\hline & Frequency & Percent & $\begin{array}{c}\text { Valid } \\
\text { Percent }\end{array}$ & $\begin{array}{c}\text { Cumulative } \\
\text { Percent }\end{array}$ \\
\hline \multirow{4}{*}{ Valid } & kurang dari 3 & 266 & 39,2 & 39,2 & 39,2 \\
& hari & 386 & 56,9 & 56,9 & 96,2 \\
& 3-6 hari & 26 & 3,8 & 3,8 & 100,0 \\
& $7-15$ hari & 678 & 100,0 & 100,0 & \\
Total & \multicolumn{5}{c}{ Sumber: pengolahan data SPSS }
\end{tabular}

Berdasarkan tabel 5, maka dapat diketahui bahwa pasien yang dirawat kurang dari 3 hari berjumlah 266 pasien, pasien yang dirawat antara $2-6$ hari berjumlah 386 pasien, pasien yang dirawat antara 7 - 15 hari berjumlah 26 pasien.

\section{IMPORTANCE AND PERFORMANCE ANALYSIS}

Grafik 1 Importance and Performance Keseluruhan

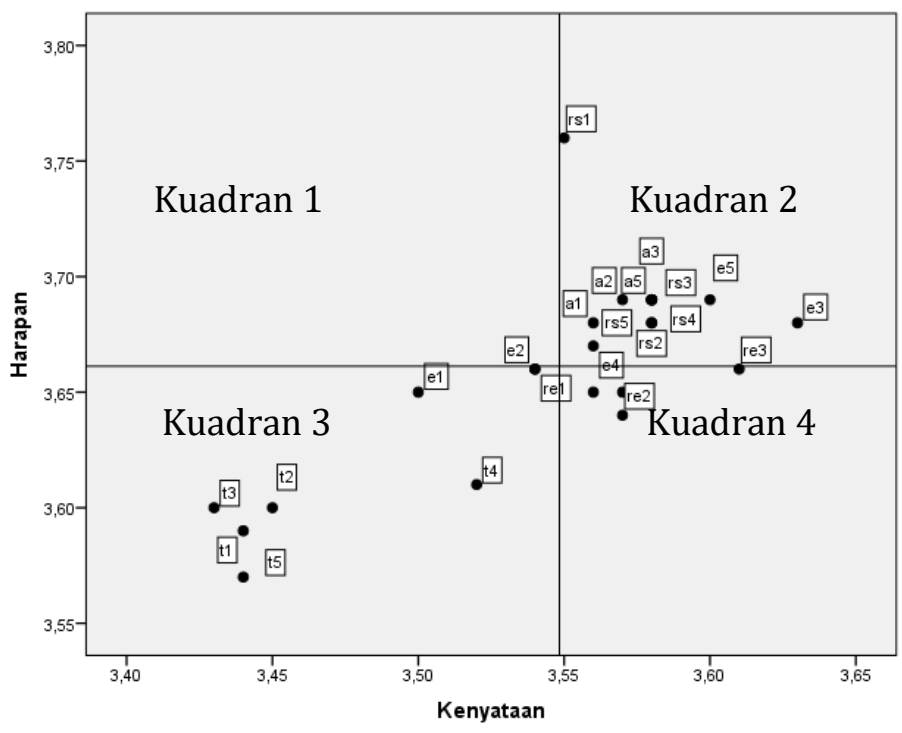


Dari grafik 1 dapat dilihat bahwa seluruh item pernyataan tidak ada yang berada di kuadran satu, sehingga secara keseluruhan untuk Importance and Performance Analysis, semua baik.

\section{UJI REGRESI BERGANDA}

Tabel 6. Uji Regresi Berganda SERVQUAL terhadap Kepuasan

\begin{tabular}{|c|c|c|c|c|c|c|}
\hline \multirow{2}{*}{\multicolumn{2}{|c|}{ Model }} & \multicolumn{2}{|c|}{$\begin{array}{l}\text { Unstandardized } \\
\text { Coefficients }\end{array}$} & \multirow{2}{*}{$\begin{array}{c}\text { Standardized } \\
\text { Coefficients } \\
\text { Beta }\end{array}$} & \multirow[t]{2}{*}{$\mathbf{t}$} & \multirow[t]{2}{*}{ Sig. } \\
\hline & & B & Std. Error & & & \\
\hline \multirow{6}{*}{1} & (Constant) & 768 & 129 & & 5,945 & 000 \\
\hline & Tangibles & 121 & 045 & 110 & 2,715 & 007 - r \\
\hline & Reliability & 047, - & 069 & 043 & 682 & 496 \\
\hline & Responsiveness & 108 & 071 & 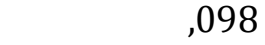 & 1,515 & 130 \\
\hline & Empathy & 122 & 041 & 136 & 2,992 & ,003 \\
\hline & Assurance & ,381 & ,066 & ,345 & 5,745 & ,000 \\
\hline
\end{tabular}

a. Dependent Variable: Kepuasan

\section{Sumber: Perhitungan SPSS versi 20}

Pada table 6 dapat dilihat bahwa tangibles, empathy dan assurance memiliki pengaruh yang signifikan terhadap kepuasan pasien karena nilai sig lebih kecil dari 0.05. Sedangkan reliability dan responsiveness tidak memiliki pengaruh yang signifikan. Tetapi semua variabel SERVQUAL memiliki pengaruh yang positif, kedaan ini dilihat dari nilai Beta Standardized Coeffcients yang mendapatkan nilai positif. Jika dimasukan dengan rumus $\mathrm{Y}=\mathrm{a}+\mathrm{b} 1 \mathrm{X} 1+\mathrm{b} 2 \mathrm{X} 2+\mathrm{b} 3 \mathrm{X} 3+\mathrm{b} 4 \mathrm{X} 4+$ b5X5, maka dapat dihitung nilai kepuasan Beta atau (B) menjadi 0,768 +0,110X1 + 0,43X2 + $0,98 \times 3+0,166 \times 4+0,345 \times 5$.

Tabel 7. Uji Pengaruh SERQUAL terhadap Kepuasan

\begin{tabular}{lrrrr}
\hline Model & R & R Square & $\begin{array}{c}\text { Adjusted R } \\
\text { Square }\end{array}$ & $\begin{array}{c}\text { Std. Error of } \\
\text { the Estimate }\end{array}$ \\
\hline 1 &, $653^{\mathrm{a}}$ &, 426 &, 422 &, 39498 \\
\hline a. Predictors: (Constant), Assurance, Tangiabel, Empathy, \\
Reliability, Responsiveness \\
r
\end{tabular}

Sumber: Perhitungan SPSS versi 20

Pada tabel 7, dapat dilihat bahwa pengaruh SERVQUAL secara keseluruhan terhadap kepuasan adalah sebesar 42,2 persen, sedangkan sisanya dipengaruhi oleh variabel lain.

Tabel 8. SERVQUAL terhadap Loyalitas Melalui Kepuasan

\begin{tabular}{|c|c|c|c|c|c|c|}
\hline \multirow{2}{*}{\multicolumn{2}{|c|}{ Model }} & \multicolumn{2}{|c|}{$\begin{array}{l}\text { Unstandardized } \\
\text { Coefficients }\end{array}$} & \multirow{2}{*}{$\begin{array}{l}\text { Standardized } \\
\text { Coefficients } \\
\text { Beta }\end{array}$} & \multirow[t]{2}{*}{$\mathrm{t}$} & \multirow[t]{2}{*}{ Sig. } \\
\hline & & B & Std. Error & & & \\
\hline \multirow{7}{*}{1} & (Constant) & ,248 & ,076 & & 3,248 & 001 \\
\hline & Tangibles &,- 015 & 026 &,- 014 &,- 590 & ,555 \\
\hline & Reliability &,- 022 & 040 &,- 021 &,- 548 & ,584 \\
\hline & Responsiveness & ,051 & ,041 & ,049 & 1,249 & ,212 \\
\hline & Empathy & ,031 & ,024 & ,035 & 1,297 & 195 \\
\hline & Assurance & 138 & ,039 & 129 & 3,513 & ,000 \\
\hline & Kepuasan & ,744 & 022 & ,771 & 33,425 &, 000 \\
\hline
\end{tabular}

a. Dependent Variable: Loyalitas

Sumber: Perhitungan SPSS versi 20 
Pada tabel 8 dapat dilihat bahwa assurance, dan kepuasan memiliki pengaruh secara signifikan karena nilai sig. Berada dibawah 0,05 dan mendapat nilai Beta sebesar 0,129 untuk assurance dan nilai Beta 0,771 untuk variabel kepuasan. Sedangkan variabel lainnya tidak berpengaruh secara signifikan. Variabel tangbles dan reliability memiliki nilai beta yang negatif yaitu -0,014 untuk tangibles dan -0,021 untuk reliability sehingga dapat diartikan bahwa semakin tinggi tangibles dan reliability akan berpengaruh negatif terhadap loyalitas secara langsung. Sehingga jika dimasukan ke dalam rumus persamaan regresi yaitu $\mathrm{Y}=\mathrm{a}+\mathrm{b} 1 \mathrm{X} 1+$ $\mathrm{b} 2 \mathrm{X} 2+\mathrm{b} 3 \mathrm{X} 3+\mathrm{b} 4 \mathrm{X} 4=\mathrm{b} 5 \mathrm{X} 5+\mathrm{Md}$, maka dapat dihitung nilai loyalitas adalah $0,248+(-0,014) \mathrm{X} 1$ $+(-0,021) \mathrm{X} 2+0,049 \mathrm{X} 3+0,035 \mathrm{X} 4+0,129 \mathrm{X} 5+0,744 \mathrm{Md}$.

Tabel 9. Pengaruh SERVQUAL Terhadap Loyalitas Melalui

Kepuasan

\begin{tabular}{|c|c|c|c|c|}
\hline Model & $\mathbf{R}$ & R Square & $\begin{array}{l}\text { Adjusted R } \\
\text { Square }\end{array}$ & $\begin{array}{l}\text { Std. Error of } \\
\text { the Estimate }\end{array}$ \\
\hline 1 &, $892^{\mathrm{a}}$ & ,795 & ,793 & 22783, \\
\hline
\end{tabular}

Sumber: Perhitungan SPSS versi 20

Pada tabel 9 dapat dilihat bahwa pengaruh masing-msing variabel terhadap loyalitas adalah sebesar 79,3 persen, sedangkan sisanya di pengaruhi oleh variabel lain.

UJI ANALISIS JALUR (PATH ANALYSIS)

Analisis jalur digunakan untuk melihat seberapa besar nilai kepuasan terhadap loyalitas, maka dapat digambarkan dengan kerangka pemikiran seperti di bawah ini;

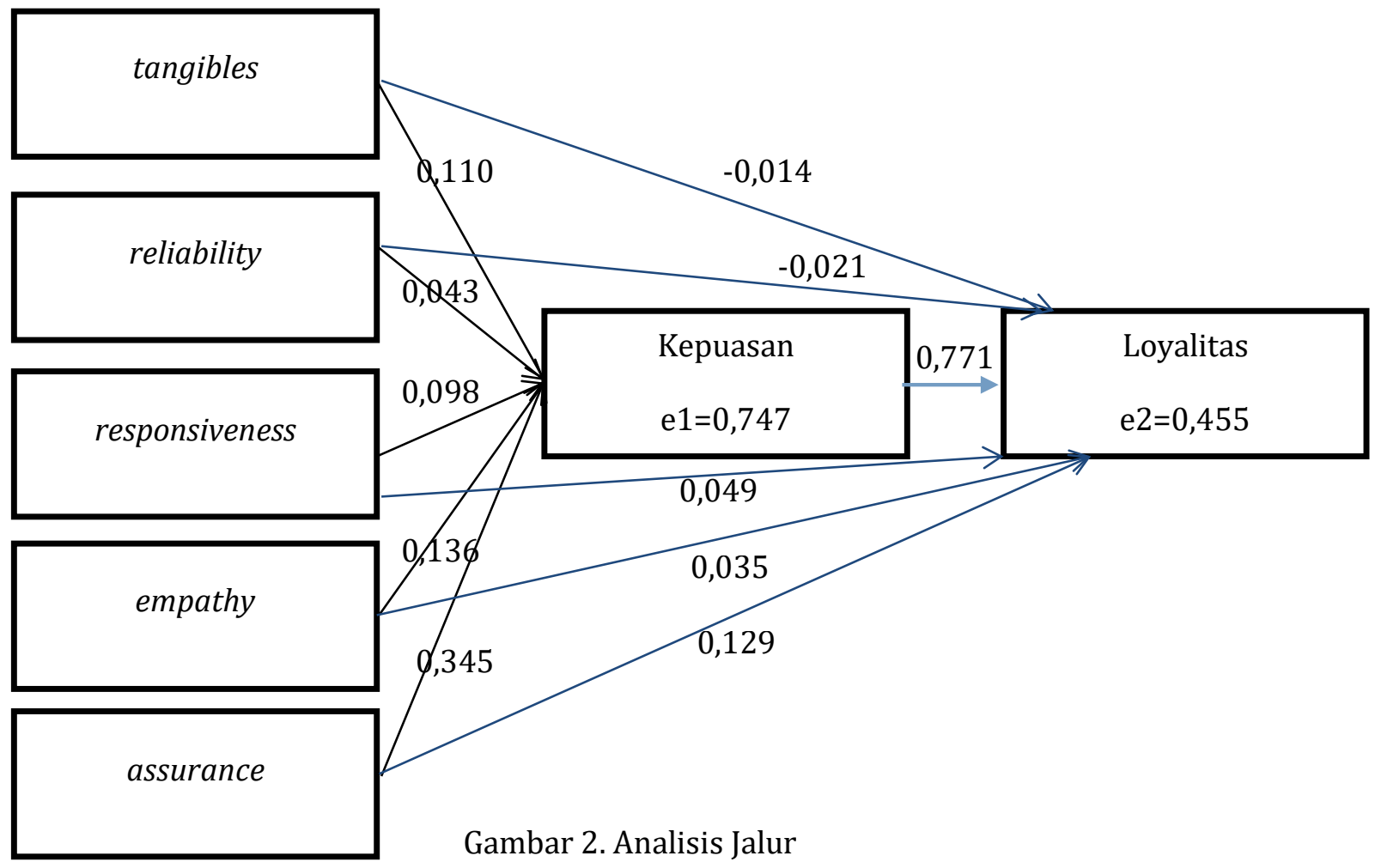

Dari gambar 2 dapat diketahui bahwa nilai kepuasan berpengaruh sebesar 0,747 sehingga jika gabungkan dengan nilai variabel bebas yang langsung menuju loyalitas tanpa melalui kepuasan menjadi lebih kecil, sehingga dapat disimpulkan bahwa nilai kepuasan memiliki pengaruh untuk menaikan nilai loyalitas. 


\section{PENGUJIAN HIPOTESIS}

Tabel 10 Pengujian Hipotesis Secara Simultan

\begin{tabular}{lrr}
\hline & $\begin{array}{l}\text { Pengaruh langsung } \\
\text { terhadap Loyalitas }\end{array}$ & $\begin{array}{l}\text { Pengaruh tidak langsung } \\
\text { terhadap Loyalitas melalui } \\
\text { Kepuasan }\end{array}$ \\
\hline Tangiable & $-0,014$ & 0,071 \\
Reliability & $-0,021$ & 0,012 \\
Responsiveness & 0,049 & 0,125 \\
Empathy & 0,035 & 0,140 \\
Assurance & 0,129 & 0,395 \\
\hline
\end{tabular}

Sumber: Intrepretasi olah data SPSS versi 20

Pada tabel 10 dapat dilihat bahwa nilai Beta Standardized Coefficients variabel bebas tangibles, reliability, responsiveness, empathy, dan assurance memiliki peningkatan nilai melalui variabel kepuasan, sehingga dengan kata lain variabel kepuasan meningkatkan variabel loyalitas. Sehingga, Hi diterima dan Ho ditolak.

Ho: Tidak terdapat pengaruh Kualitas Pelayanan terhadap Loyalitas melalui Kepuasan Pasien pada Rumah Sakit Sekar Kamulyan.

Hi : Terdapat pengaruh Kualitas Pelayanan terhadap Loyalitas melalui Kepuasan Pasien pada Rumah Sakit Sekar Kamulyan

Tabel 11 Pengujian Hipotesis

\begin{tabular}{llccl}
\hline No & Hipotesis & Diterima & Ditolak & \multicolumn{1}{c}{ Hasil } \\
\hline 1 & $\mathrm{X} 1-\mathrm{Md}$ & $\mathrm{v}$ & & "+ / Signifikan" \\
2 & $\mathrm{X} 2-\mathrm{Md}$ & & $\mathrm{V}$ & "+ / Tidak Signifikan" \\
3 & $\mathrm{X} 3-\mathrm{Md}$ & & $\mathrm{V}$ & "+ / Tidak Signifikan" \\
4 & $\mathrm{X} 4-\mathrm{Md}$ & $\mathrm{V}$ & & "+ / Signifikan" \\
5 & $\mathrm{X} 5-\mathrm{Md}$ & $\mathrm{V}$ & & "+ / Signifikan" \\
6 & $\mathrm{Md}-\mathrm{Y}$ & $\mathrm{V}$ & & "+ / Signifikan" \\
7 & $\mathrm{X} 1-\mathrm{Md}-\mathrm{Y}$ & & $\mathrm{V}$ & "- / Tidak Signifikan" \\
8 & $\mathrm{X} 2-\mathrm{Md}-\mathrm{Y}$ & & $\mathrm{V}$ & "- / Tidak Signifikan" \\
9 & $\mathrm{X} 3-\mathrm{Md}-\mathrm{Y}$ & & $\mathrm{V}$ & "+ / Tidak Signifikan" \\
10 & $\mathrm{X} 4-\mathrm{Md}-\mathrm{Y}$ & & $\mathrm{V}$ & "+ / Tidak Signifikan" \\
11 & $\mathrm{X} 5-\mathrm{Md}-\mathrm{Y}$ & $\mathrm{v}$ & & "+ / Signifikan" \\
\hline \multicolumn{5}{c}{ Sumber: Intrepretasi olah data SPSS }
\end{tabular}

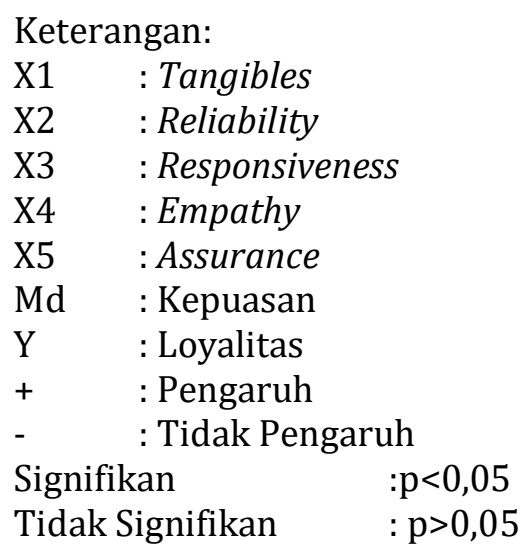

Pada tabel 11 dapat diambil penarikan hipotesis sebagai berikut : 
Pengaruh Kualitas Layanan Pasien Rawat Inap Terhadap Loyalitas di Rumah Sakit Sekar Kamulyan dengan Kepuasan Sebagai Variabel Mediasi

Tangibles berpengaruh secara signifikan terhadap kepuasan pasien umum di ruang rawat inap dengan nilai sebesar 0,110

Realibility berpengaruh tetapi tidak signfikan terhadap kepuasan pasien di ruang rawat inap dengan nilai 0,043 .

Responivesness tidak berpengaruh secara signifikan terhadap kepuasan pasien di ruang rawat inap dengan nilai 0,098.

Assurance berpengaruh secara signifikan terhadap kepuasan pasien di ruang rawat inap dengan nilai 0,345.

Empathy berpengaruh secara signifikan terhadap kepuasan pasien di ruang rawat inap dengan nilai 0,136.

Kepuasan berpengaruh secara signifikan terhadap loyalitas pasien di ruang rawat inap sebesar 0,771, dengan tingkat signifkansi 0,000

Tangibles tidak berpengaruh secara signifikan terhadap loyalitas pasien melalui mediasi Kepuasan di ruang rawat inap dengan nilai sebesar -0,014.

Realibility tidak berpengaruh terhadap loyalitas pasien melalui mediasi Kepuasan di ruang rawat inap dengan nilai $-0,021$.

Responivesness berpengaruh tetapi tidak secara signifikan terhadap loyalitas pasien melalui mediasi Kepuasan di ruang rawat inap dengan nilai 0,049.

Assurance berpengaruh secara signifikan terhadap loyalitas pasien melalui mediasi Kepuasan di ruang rawat inap dengan nilai 0,129.

Empathy berpengaruh akan tetapi tidak secara signifikan terhadap loyalitas pasien melalui mediasi Kepuasan di ruang rawat inap dengan nilai 0,035.

\section{PEMBAHASAN}

Pembahasan dalam penelitian ini adalah dari data sosio demografis dapat dilihat pasien peserta Jaminan Kesehatan Nasional (JKN) di Rumah Sakit Sekar Kamulyan lebih didominasi oleh pria, dengan rentang usia 25 - 34 tahun, dengan pekerjaan pegawai swasta, dan berpendidikan akhir SLTA, dan banyak yang menginap selama 3 - 6 hari.

Pada uji regresi dapat dilihat bahwa tangibles, assurance, dan empathy memiliki pengaruh yang signifikan terhadap kepuasan, hasil ini sesuai dengan penelitian yang dilakukan oleh Ulfa,S., dan Zulkarnain,A. (2016), yang mengatakan tangibles, dan assurance berpengaruh terhadap kepuasan pasien rawat inap. Sedangkan empathy adalah hasil baru dari penelitian ini yang ternyata juga memiliki pengaruh terhadap kepuasan pasien.

Secara keseluruhan, kualitas pelayanan berpengaruh terhadap kepuasan pasien di Rumah Sakit Sekar Kamulyan sebesar 42,6\%. Hasil ini lebih kecil dibandingkan penelitian yang dilakukan oleh Suzanto, B.(2011) di Rumah Sakit Umum Kota Banjar, yang mengatakan kualitas layanan berpengaruh terhadap kepuasan pasien sebesar 73,7\%.

Perbedaan keadaan ini dapat disebabkan perbedaan fasilitas setiap Rumah Sakit penelitian. Rumah Sakit Sekar kamulyan adalah rumah sakit tipe C dengan fasilitas sesuai standar fasilitas dan pelayanan rumah sakit tipe $C$ sehingga setiap pasien yang datang ke rumah sakit tidak semua dapat dilayani karena penyakitnya. Peraturan Menteri Kesehatan no. 28 tahun 2014 tentang Pedoman Pelaksanaan Program Jaminan Kesehatan Nasional menyebutkan adanya rujukan berjenjang ke rumah sakit dengan fasilitas yang lebih tinggi ketika fasilitas di rumah sakit yang dituju tidak tersedia.

Kepuasan pasien rawat inap di Rumah Sakit Sekar Kamulyan berpengaruh signifikan dan secara positif terhadap loyalitas, dan pengaruh antara kepuasan dengan loyalitas sangat kuat di Rumah Sakit Sekar Kamulyan. Keadaan ini sesuai dengan penelitian yang dilakukan oleh Rosiana Rizal, Muslim Suardi, \& Yulihasri (2017), yang mengatakan bahwa kepuasan memiliki pengaruh secara positif terhadap loyalitas

Pada penelitian ini dimensi kualitas layanan yang memiliki pengaruh secara langsung dengan loyalitas adalah assurance, dan kepuasan memiliki pengaruh secara signifikan, sedangkan variabel lainnya tidak berpengaruh secara signifikan. Variabel tangibles dan reliability memiliki nilai beta yang negatif sehingga dapat diartikan bahwa semakin tinggi 
tangibles dan reliability akan berpengaruh negatif terhadap loyalitas secara langsung. Penelitian ini juga melihat pengaruh langsung terhadap loyalitas dan pengaruh secara tidak langsung yang dilalui oleh kepuasan, dan mendapatkan hasil bahwa adanya pengaruh tidak langsung yang berpengaruh terhadap loyalitas, keadaan ini menguatkan bahwa kepuasan memiliki pengaruh terhadap loyalitas. Pada penelitian ini, dilihat dari nilai Beta Standardized Coefficients terhadap variabel bebas yaitu tangibles, reliability, responsiveness, empathy, dan assurance memiliki peningkatan nilai melalui variabel kepuasan

Berdasarkan analisis Importance and Performance yang berguna untuk mengetahui item atau bagian apa yang sebaiknya diperbaiki oleh pihak rumah sakit, semua aspek kualitas layanan sudah bagus karena tidak ada yang berada di kuadran 1. Berdasarkan analisis Importance and Performance item-item pernyataan banyak yang berada di kuadran 2. Akan tetapi, item responsiveness nomor 1 yang berbunyi "Dokter bersedia menanggapi keluhan pasien" dekat dengan nilai rata-rata sehingga perlu dilakukan perbaikan agar tidak beralih ke kuadran satu.

\section{KESIMPULAN DAN IMPLIKASI}

\section{KESIMPULAN}

Kesimpulan dari penelitian ini adalah assurance berpengaruh secara signifikan terhadap kepuasan pasien di ruang rawat inap sebesar 0,345. Variabel tangibles berpengaruh secara signifikan terhadap kepuasan pasien di ruang rawat inap sebesar 0,110; empathy berpengaruh secara signifikan terhadap kepuasan pasien di ruang rawat inap dengan nilai 0,136 . Sedangkan variabel reliability dan responsiveness, tidak berpengaruh secara signifikan terhadap kepuasan pasien di ruang rawat inap. Kepuasan berpengaruh secara signfinikan terhadap loyalitas pasien di ruang rawat inap dan menambah loyalitas sebesar 0,771 .

\section{IMPLIKASI TEORITIS}

Peneliti memberikan saran akademis untuk penelitian berikutnya adalah dengan menambahkan variabel kepercayaan pasien. Keadaan ini dikarenakan data jumlah pasien di rumah sakit meningkat setiap tahunnya. Jumlah pasien yang meningkat dapat dikategorikan sebagai peningkatan rasa kepercayaan pasien terhadap brand, dalam hal ini adalah Rumah Sakit Sekar kamulyan.

\section{IMPLIKASI MANAJERIAL}

Peneliti memberi saran praktis kepada manajemen Rumah Sakit Sekar kamulyan sebaiknya untuk tidak berfokus pada fasilitas saja, karena berdasarkan hasil analisis Importance and Performance untuk fasilitas tidak mendapatkan nilai tinggi dalam harapan terhadap rumah sakit. Akan tetapi, meskipun mendapatkan nilai yang rendah, fasilitas memiliki pengaruh terhadap loyalitas melalui variabel kepuasan

Saran selanjutnya untuk manajemen Rumah Sakit Sekar Kamulyan adalah nilai variabel assurance yang mendapat nilai tinggi pada harapan dan kenyataan, dan memiliki pengaruh yang signifikan terhadap loyalitas melalui variabel kepuasan, sehingga perlu adanya perhatian pihak manajemen untuk mempertahankan variabel assurance, seperti dokter melayani dengan sikap meyakinkan sehingga pasien merasa aman, mendapatkan nilai tertinggi baik kenyataan maupun harapan dari pasien.

Saran praktis selanjutnya untuk manajemen yang dirasa perlu perbaikan adalah hasil Importance and Performance Analysis secara keseluruhan, tidak ada. Karaena dari analisa Importanve and Performance tidak ada item pernyataan yang berada dikuadran 1 . Akan tetapi jnika pihak manajemen akan memperbaiki sebaiknya dilakukan perbaikan pada item pernyataan "Dokter bersedia menanggapi keluhan pasien" atau item pernyataan responsiveness no 1, dikarenakan dekat dengan nilai rata-rata tampilan kurang . keadaan ini sesuai dengan yang dikeluhkan pasien pada data kritik dan saran Rumah Sakit Sekar Kamulyan semester 1 tahun 2018 mengenai pelayanan dokter, yaitu penjelasan dokter tentang penyakit kepada 
pasien dan keluarga kurang, dokter terlalu buru-buru saat memeriksa pasien di ruang perawatan. Selain itu adanya keluhan petugas pendaftaran, petugas laboratorium, petugas radiologi serta petugas farmasi kurang ramah dan waktu tunggu di farmasi lama.

\section{KETERBATASAN PENELITIAN}

Keterbatasan penelitian yang dirasakan peneliti adalah belum begitu menggambarkan keseluruhan responden, dan responden yang didapat kurang dapat terbuka dikarenakan metode penelitian yang dilakukan adalah metode penelitian kuantitatif, sehingga kurang mendapatkan hasil yang lebih detail.

\section{DAFTAR PUSTAKA}

Jurnal

Abdurrouf, M. dan Sari, D.W. 2017. Model Loyalitas Pasien Berbasis Kualitas Pelayanan Rumah Sakit Islam di Semarang. Jurnal Kesehatan, Volume VIII,Nomor 3, November 2017, hlm. 435 - 440.

Ahmed, S., Tarique, K., and Arif, I. 2017. Service quality, patient satisfaction and loyalty in the Bangladesh healthcare sector. International Journal of Health Care Quality Assurance. Vol.30. Issue: 5.

Atinga, R. 2012. Healthcare quality under the national health inssurance scheme in Ghana. International Journal of Quality \& Reliability Management. Vol. 29. Iss 2. pp. 144-161.

Badri, M., Attia, S. and Ustadi, A. 2009. Healthcare quality and moderators of patient satisfaction: testing for causality. International Journal for Quality in Healthcare. Vol. 22 . No. 4 . pp. 382-410.

Budiadji, W.2013. Skala Pengukuran dan Jumlah Respon Skala Likert. Jurnal Ilmu Pertanian dan Perikanan. Vol. 2. No. 2. Hal : 127-133.

Chakraborty, R. and Majumdar, A. 2011. Measuring consumer satisfaction in health care sector : the applicability of servqual. International Refereed Research Journal. Vol II . Issue 4.

Chang et al. 2013. Service quality, trust, and Patient satisfaction in interpersonal-based medical service encounters. BMC Health Service Research. Vol. $13: 22$.

Denziana, A., Indrayenti, dan Fatah, F. 2014, Corporate Financial Performance Effects of Macro Economic Factor Againts Stock Return. Jurnal Akutansi dan keuangan Vol. 5, No. 2, Septermber 2014, pp. 17-40.

Emmanuel, K., Atinga, R. and Adzei, F. 2012. Managerial problem of hospital under Ghana's National Health Insurance Scheme. Clinical Governance : An International Journal. Vol. 17. Iss 3. pp. 178-190.

Ferrinadewi, E., \& Djati, S. P. 2004. Upaya Mencapai Loyalitas Konsumen dalam Perspektif Sumber Daya Manusia. Jurnal Jurusan Ekonomi Management, Fakultas Ekonomi, Universitas Kristen Petra.

Frimpong, N., Nwankwo, S. and Doson, B. 2010. Measuring service quality and patient satisfaction with acces to public and private healthcare delivery. International Journal for Quality in Healthcare. Vol. 23. No. 3. Pp 203-220.

Hayati, N. 2012. Pemilihan metode yang tepat dalam penelitian (metode kuantitatif dan kualitatif). Jurnal Tarbiyah al-Awlad, Volume IV, Edisi 1. pp 345-357.

Kartikasari, D., Dewanto, A., dan Rochman, F. 2014. Pengaruh Kualitas Layanan terhadap Kepuasan dan Kepercayaan di Rumah Sakit Bunda Kandangan Surabaya. Jurnal Aplikasi Management (JAM), Vol. 12. No. 3.

Khandakar, S. 2007. Doctors, service orientation in public, private, and foreign hospital. International Journal of Health Care Quality Assurance. Vol. 20. Iss 3. pp.235-263.

Kim, D. J., Ferrin, D. L., and Rao, H. R. 2003. Antecedents of Consumer Trust in B-to-C Electronic Commerce. Proceeding of the American Conference on Information System 2013, 157 - 167. Reschearch Collection Lee Kong Chian School of Business.

Kulsum, U. 2017. The Effect of Service Quality on Loyalty with Mediation of Patient Satisfaction. International Journal of Business and Management Invention. Vol. 6 .Issue.3. pp. 41-50.

Lee, S., Arti, W., and Zhang, K. 2007. The quest to improve chinese health care : some fundamental issues. International Journal of Health Care Quality Assurance. Vol. 20. No. 5. pp. 416-428. 
Muffatto, M., and Panizzolo, R. 1995. A process-based view for customer satisfaction. International Journal of Quality \& Reliability Management. Vol. 12. no. 9. Pp. 154-169.

Naidu, A. 2009. Factors affecting patient satisfaction and healthcare quality. International Journal for Quality in Healthcare. Vol. 22. No. 4.pp.366-381.

Nesa, C.M., Umboh, J., dan Doda, D. 2017. Analisis Hubungan Kualitas Pelayanan Terhadap Kepuasan Pasien Peserta BPJS di Instalasi Rawat Inap Rumah Sakit TNI AU Lanud Sam Ratulangi Manado. Majalah Farmaseutik. Vol.2. No. 1.

Olsen, L., Witell, L., and Gustafsson, A. 2014. Turning customer satisfaction measurements into action. Journal of Service Management. Vol.25. Iss. 4 . pp. 556-571.

Pasuraman, A., Zeithaml, V., and Berry, L. 1988. SERVQUAL : multiple-item scale for measuring consumer perceptions of service quality. Journal of Retalling. Vol. 64.

Quaye, R. 2007. Health care financing in Uganda : the role of social health insurance. International Journal of Health Care Quality Assurance. Vol. 20. Iss. 3. pp.232-239.

Rizal, R., Suardi, M., dan Yulihasri. 2017. Pengaruh Kualitas Pelayanan dan Kepuasan Pasien Peserta BPJS Kesehatan sebagai Mediasi terhadap Loyalitas Pasien. Jurnal Sains Farmasi \& Klinis 3 (2)

Russell, R., Johnson, D., and White, S. 2015. Patient perception of quality : analyzing patient satisfaction survey. International Journal for Quality in Healthcare. Vol.35. Iss.8. pp.1158-1181.

Sharma, R., Sharma, M., and Sharma, R.K. 2011. The patient satisfaction study in a multispecilaty tertiary level hospital, PGIMER, Chandigarh, India. Journal Leadership in Health Service. Vol. 24. no. 1. pp.6473.

Siswati, S. 2015. Kualitas Pelayanan Kesehatan Dengan Kepuasan Pasien BPJS Di Unit Rawat Inap RSUD Kota Makasar. Jurnal MKMI. hal. 174-183.

Sullivan, D. and McCallig, J. 2010. Customer satisfaction, earnings and firm value. European Journal of Marketing. Vol.46. no.6. pp 827-843.

Sumedi, S., Bakti, I. Rakhmawati, T., Astrini, J., Widianti, T., and Yarmen, M. 2016. Indonesian public healthcare service institution's patient satisfaction barometer (IPHSI-PSB). International Journal of Productivity and Performance Management. Vol. 65. Iss. 1 pp. 25 - 41.

Suzanto, B. 2011. Pengaruh Kualitas Jasa Pelayanan Terhadap Kepuasan Pasien Pada Rumah Sakit Umum Kota Banjar. Jurnal Ekonomi, Bisnis \& Entrepreneurship. Vol. 5, No. 1, April 2011, 28 - 44. ISSN 2443-0633

Sumber Internet

detikHealth.2015. Ini 4 Keluhan Utama Soal Pelayanan BPJS menurut YLKI. https://health.detik.com/berita-detikhealth/d-2865854. Diakses tgl. 27 Juli 2018.

Triyono, A. 2015. Ini Permasalahan Penting di BPJS Kesehatan. http://ekonomi.Kompas.com/read/2015/01/06/130228826. Diakses tgl. 27 Juli 2018.

Suryowati,S. 2017. Riset Prakarsa : Pasien BPJS Kesehatan Merasa Dokter Kurang Peduli. https://nasionalkompas.com/read/2017/05/23/19164281. Diakses tgl. 27 Juli 2018.

Wilson, T. 2016. Assessing the relationship between patient satisfaction and clinical quality in an ambulatory setting. Journal of Health Organization and Management. Vol. 30 .Iss .7 .

Ulfa, S., dan Zulkarnain, A. 2016. Analisis kepuasan pasien rawat inap pengguna terhadap kualitas pelayanan di bangsal kebidanan dan kandungan RSUD Sleman Yogyakarta. Majalah Farmaseutik. Vol. 12. No. 2.

Buku

Ghozali, I. 2009. Ekonometrika : Teori, Konsep dan Aplikasi Dengan SPSS 17. Badan Penerbit Universitas Diponegoro.

Kemenkes. 2013. Permenkes RI, No. 69 .Tentang Standar Tarif Pelayanan Kesehatan pada Fasilitas Kesehatan Tingkat Pertama dan Fasilitas Kesehatan Tingkat Lanjutam Dalam Penyelenggaraan Program Jaminan Kesehatan. Jakarta. 
Pengaruh Kualitas Layanan Pasien Rawat Inap Terhadap Loyalitas di Rumah Sakit Sekar Kamulyan dengan Kepuasan Sebagai Variabel Mediasi

Kemenkes. 2013. Permenkes RI, No. 71. Tentang Pelayanan Kesehatan Pada . Jakarta.

Kemenkes. 2013. Permenkes RI, No. 455. Tentang Asosiasi Fasilitas Kesehatan. Jakarta.

Kemenkes. 2014. Permenkes RI, No. 28. Tentang Pedoman Pelaksanaan Program . Jakarta.

Kemenkes. 2014. Permenkes RI, No. 159. Tentang Perubahan Atas Keputusan Menteri Kesehatan nomor 328/MENKES/SK/IX/2013 tentang Formularoum Nasional. Jakarta.

Kemenkes. 2014. Permenkes RI, No. 27 . Tentang Petunjuk Teknis Sistem Indonesian Case Base Groups (INA-CBGs). Jakarta

Kemenkes. 2014. Permenkes RI, No. 27 . Tentang Petunjuk Teknis Sistem Indonesian Case Base Groups (INA-CBGs). Jakarta.

Kotler, P., and Armstrong, G. 2011. Principle Of Marketing, 11 th edition. New Jersey: Pearson Prentice Hall.

Mas'ud, F. 2004. Survai Diagnosis Organisasional Konsep dan aplikasi. Badan Penerbit Universitas Diponegoro.

Solomon, M.R. 2013. Consumer Behavior. 11 th edition. Saint Joseph,s University.

Solomon, M.R. 2015. Consumer Behavior : Buying, Having and Being. Saint Josep's University and The University of Manchester .UK. ed. $11^{\text {th }}$.

Sugiyono. 2017. Statistik untuk Penelitian. Penerbit Alfabeta. Bandung.

Thabrany, H. 2003. Tinjauan Akademis Tentang Asuransi Kesehatan Nasional. Pusat Kajian Ekonomi Kesehatan, Universitas Indonesia.

Widhiarso, W. 2010. Uji Linearitas Hubungan. Fakultas Psikologi UGM. 